\title{
FARSB wt Allele
}

National Cancer Institute

\section{Source}

National Cancer Institute. FARSB wt Allele. NCI Thesaurus. Code C54256.

Human FARSB wild-type allele is located 2q36.1 and is approximately $86 \mathrm{~kb}$ in leng th. This allele, which encodes phenylalanyl-tRNA ligase beta subunit protein, plays a role in the mediation of translation through the regulation of the synthesis of amino acid/transfer RNA complexes. 